\title{
ОПШТИ ОДНОСИ ИРОНИЈЕ И САРКАЗМА ${ }^{1}$
}

Универзитет у Крагујевцу Филолошко-уметнички факултет

Апстракт: Предмет рада представља анализу природе, облика и функција ироније и сарказма, од процеса стварања и перципирања ироничних и саркастичних исказа, преко њихових ефеката и интерференције у оквиру иронијског дискурса, до структурирања и исхода ироније ситуације у говорном чину и у књижевно-уметничком делу. Опште односе ироније и сарказма проучавали смо посредством интердисциплинарног приступа: од реторичких, преко прагматичких, семантичких, до стилистичких и филозофских домена. На тај начин смо објединили синхронијску и дијахронијску перспективу, аналитичко-синтетичком методом.

Наш научни допринос се састоји и у разматрању односа надмоћности и потчињености у ироничним и саркастичним исказима и ситуацијама, степенима сугерисања, прикривања и откривања иронијске интенције, као и питања раслојавања сарказма - у случајевима у којима сарказам представља врсту ироније, у односу на случајеве у којима је евидентнија аутономнија позиција сарказма у односу на иманентне одлике ироније. Запазили смо да се примери сарказма који у својој основи имају кључна обележја иронијског дискурса (претварање, противречност, супротност значења) могу сматрати врстама јетке ироније, док примери сарказма који немају изражене наведене особине, већ поседују отворенији став надмоћности којим се може и директније увредити саговорник - самим тим имају самосталније домене деловања.

Кључне речи: иронија, сарказам, интердисциплинарност, иронијска интенција, супротност, сатира, пародија

\section{Увод}

У друштвено-хуманистичким наукама постоји обимна литература о природи, функцијама и облицима ироније, од ироничног исказа до општег иронијског дискурса, пошто иронија представља фигуру критичког става: од синтаксичког до интердиксурзивног нивоа, као и од реакције на постојећу ситуацију до општег система поимања света.

Међутим, поред многобројних специјализованих теорија ироније, није довољно развијена свест о међусобној комуникацији дисциплина, да би се, у обједињеном виду, анализирале различите перспективе овог сложеног језичког, стилског, психичког и фило-

1 Рад је део истраживања на пројекту 178018 Друшиивене кризе и савремена срйска кюи-

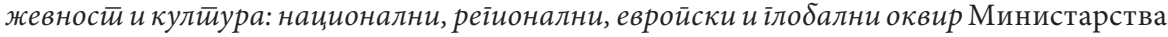
просвете, науке и технолошког развоја Републике Србије. 
зофског феномена. Дакле, за проучавање тоталитета значења ироније, као и њеног односа према сарказму, неопходна је свест о комплементарности наука, у интердисциплинарном приступу.

С друге стране, у теорији књижевности није довољно пажње посвећено проучавању сарказма, већ се најчешћи поступак састоји у кратком опису везаном за општу назнаку подређености принципу ироније, а остају нерасветљена питања облика, степена и слојева сарказма. Сарказму у комуникацији више је пажње посветила прагматика, али прагматичке теорије могу имати само делимичну примену у анализи сарказма у књижевно-уметничком делу.

Да бисмо објаснили природу односа сарказма и ироније, у раду ћемо објединити синхронијску и дијахронијску перспективу: од античког поимања ироније, аспеката лингвостилистике и књижевне стилистике, до савремених теорија у прагматици. У општем смислу, иронија ће бити схваћена као „чинилац дискурзивне тактике” (Стојановић 2003: 21), тако да интерпретација „интенција ироничног дискурса” (Стојановић 2003: 23) подразумева јединство проучавања ироније ситуације и система ироничних исказа.

Предмет рада, дакле, представља анализу природе, облика и функција ироније и сарказма, од процеса стварања и перципирања ироничних и саркастичних исказа, преко њихових ефеката и интерференције у оквиру иронијског дискурса, до структурирања и исхода ироније ситуације у говорном чину и у књижевно-уметничком делу. Након овог прегледног дела рада, наш научни допринос hе се састојати у разматрању односа надмоћности и потчињености у ироничним и саркастичним исказима и ситуацијама, питањима степена сугерисања, прикривања и откривања иронијске интенције, као и питањима раслојавања сарказма - у случајевима у којима сарказам представља врсту ироније, у односу на случајеве у којима је евидентнија аутономнија позиција сарказма у односу на иманентне одлике ироније.

\section{1. Опште одлике ироније}

Од антике до савременог доба, иронија има значајну улогу у језику, филозофији и поезији (Солар 2012; Поповић 2007), богату традицију проучавања и различите видове тумачења, од питања њене етимологије, до разноврсних примена и модификација.

Анализу општих одлика ироније започињемо етимолошким аспектима: „Сам назив потјече из грчке антике. Смисао му се тијеком стољећа осјетно мијењао. Најприје се појавио појам eiron (Eiprov), који је означавао онога који пита и који се пита" (Багић 2012: 162)2.

2 Истицање полемичког духа као основе ироније присутно је и у следећој дефиницији: „Овај израз, недовољно јасног порекла, повезује се са глаголима говорити или 
Поред овог општег етимолошког упућивања на дух полемике, у рецепцији антике најупечатљивија је сократовска иронија у Платоновој филозофији - као сложен феномен који се састоји из неколико аспеката: глумљено незнање, које наводи саговорника да се изјасни и да поступно образложи своје ставове; следећи корак састоји се у Сократовом указивању на противречности и слабости саговорникових ставова, а постепено се саговорник наводи да, посредством логике, дође до истинитог закључка.

Након пресудног Сократовог гласа у Платоновој филозофији, Аристотелово одређивање ироније представља следећу кључну тачку: самопотцењивање је класично својство, као средство ироније које наводи Аристотел у Никомаховој етиици (Аристотел 1980: 104), а заправо у Ретиорищи Аристотел одређује иронију као врлину својствену слободном човеку (Аристотел 1997: 337). Тако је Аристотел проширио и универзализовао појам ироније, не само на сократовски принцип, него је отворио перспективе проучавања ироније од говорног чина до ироније ситуације.

У Образовағу іоворника Квинтилијан је, даље, под утицајем Аристотела ${ }^{3}$, дефинисао иронију преко својства: „претварања” (Квинтилијан 1985: 294) ${ }^{4}$ и супротности значења, сматрајући да је иронија и фигура речи и фигура мисли, коју „треба разумети обрнуто од онога што се говори" (Квинтилијан 1985: 302). ${ }^{5}$

Тако се ово поимање античке реторике обликовало и у савременој лингвостилици ${ }^{6}$ и књижевној стилистици, као доминантно тумачење по коме се у иронији (грч. eironeia= претварање) „речима даје

питати” (...) „означава поступак онога који поставља питања претварајући се да сам не зна одговор, или онога који нешто намерно прећуткује и каже мање него што мисли" (Марицки Гађански, Лазаревић 1985: 275).

3 „Римљани су иронију још називали dissimulatio (Ciceron), illusio (Kvintilijan) i simulatio (Akvila Rimljanin)” (Багић 2012: 165).

4 „Иронија, (хеленски єір $\omega v \varepsilon i \alpha^{-}$претварање, претворство)” (Тартаља 1998: 152).

5 „А да треба разумети обрнуто, у говору се даје на знање интонацијом, у писању контекстом" (Тартаља 1998: 152). Као илустрацију овог става, Тартаља наводи пример говора Марка Антонија у Шекспировом Јулију Цезару, чија је суштина одређена реченицом „А Брут је човек частан” (Тартаља 198: 152).

6 Истичемо значај Ковачевићевог одређивања ироније кроз „фигуре хармоничног противурјечја” (М. Ковачевић 2000: 115) у које спадају: парадокс, оксиморон, антиметабола, антитеза, иронија, хипербола и литота. „У основи је свих тих фигура нека врста противурјечности или супротности” (...) „иронија (у којој је задати смисао супротан ономе што је казано, као нпр.: Баш сте паметни! = Луди сте” (М. Ковачевић 2000: 115). Дакле, Милош Ковачевић прецизира елементе противречности у иронији, тако да је његово лингвостилистичко одређивање применљивије од општих књижевнотеоријских схватања реторичког наслеђа, у доменима проучавања говорног чина, као и у ширем смислу - у анализи ироније ситуације. Пошто је предмет рада везан за опште одлике односа ироније и сарказма, односи ироније и других стилских фигура су на овом месту приказани на нивоу илустрације, док би детаљна анализа представљала предмет посебног рада. 
супротан смисао од оног које имају у основном свом значењу, а та супротност значења извире из контрастне ситуације у којој се та реч доводи намерно у несклад са околним текстом" (Живковић 1971: 88).

Међутим, крајем двадесетог века, у прагматици се јавља теорија Вилсона и Спербера (Deirdre Wilson, Dan Sperber), по којој иронични искази не морају увек имати супротно значење (уп. Вилсон, Спербер 1981: 295; Вилсон, Спербер 1992: 54-56). На пример, они наводе случајеве ублаженог ироничног исказа (енгл. ironical statement): Чини ми ce ga йaga кuша, који, пре свега, има иронично значење у случају већег пљуска; додајмо да је иронично значење потенцирано посебно ако говорници осећају директне последице временске непогоде. Дакле, у овом примеру, значење није супротно, већ ублажено (Веркман 2011).

Након ове теорије, било је потребно направити синтезу традиције и савремених проучавања ироније и имплицитно довести у везу све претходне аспекте. На пример, у Рјечнику сииилских фьиіу$p a$, Багић наводи да се иронија „заснива на различитости. Иронија увијек претпоставља трајање. За њезино је разумијевање потребно бар толико времена колико захтијева 'превођење' антифразе" (Багић 2012: 165). У овом одређивању Багић тежи, у духу енциклопедизма, да обједини претходне теорије, али ипак наводећи примере са претежно супротним значењем.

На основу наведених аспеката, закључујемо да је „претварање” основно обележје ироније, чија је сврха превасходно супротно значење од привидно изреченог, односно -противречност која је у основи ироније, док су примери ублажених израза знатно ређи и представљају самим тим само изузетке од правила, како у говорном чину тако и у књижевно-уметничком делу, али их је ипак неопходно прецизирати, не да би се оспорила теорија супротног значења (Проп 1984: 111), већ да би се стекла свест о варирању, слојевитости и нијансама ироније.

\section{2. Класификација облика ироније}

У разноликости употреба и функција наводимо основне облике ироније:

1. Вербална иронија - принцип који може бити присутан у свим облицима и врстама ироније; Шоентјес (P. Schoentjes) објашњава овај сложени језички феномен кроз реторички дискурс (Шоентјес 2001), са супротним смислом и са сврхом уверавања (Багић 2012: 162).

2. Сократовска иронија, чија се суштина налази у изреци „Знам да ништа не знам”, заправо сведочи о глумљеном незнању, а суштинској мудрости у којој ће постепено навести саговорника да преиспита сопствена становишта, а низом оштроумних питања „у циљу отклањања туђих заблуда” (Тартаља 1998: 152), Сократ отвара 
путеве откривања истине. На пример, у Филебу, посредством ироније, Сократ заправо сугерише значај прецизних класификација у филозофској спознаји: „А ја сам, изгледа, неки смешан човек кад толико инсистирам на подели на врсте и пребројавању" (Платон 1983: 73). Тако сократовска племенита иронија постаје педагошки метод, принцип филозофске спознаје, као и уопште - обележје Сократовог и Платоновог начина поимања света.

3. Иронија ситуације, коју Шоентјес објашњава кроз драмски дискурс, чија је сврха „показивање живота” (Багић 2012: 162), у преобратима и динамичности контекста (Шоентјес 2001). Пошто има универзалну сврху, појам ироније ситуације остварује се од контекста говорних ситуација и деловања говорника, до њене употребе у књижевно-уметничком делу, чији је најупечатљивији облик драмска (трагичка) иронија, која се састоји, с једне стране - у знању или предвиђању публике о будућем трагичном исходу јунака, и с друге - у трагичном незнању протагонисте (Аристотел 2002), због кога и чини трагичну кривицу; због своје доследности и погрешних претпоставки у деловању он постаје жртва трагичне судбине.

4. Романтична иронија, која се заснива на јединству супротности између идеала и меланхолије, између идеје генијалне надмоћи и отуђења, а у односима приказивања стварности и фикције доминантно је „такво мешање измишљеног света са светом познатим, разбијање причом створене илузије стварности” (Тартаља 1998: 154).

5. Иронијски дискурс постмодернизма, у коме је доминантан „иронијски отклон” (Лешић 210: 249), у плурализму идејних перспектива - од преиспитивања и преображаја традиције, до преиспитивања властитог стваралачког поступка.

\section{3. Интенције ироније}

Једно од кључних питања објашњења феномена ироније везано је за интенције пошиљаоца, степене прикривања и откривања ироније, као и ефекта који иронични исказ има на примаоца. У овом контексту, карактеристично је Грајсово (Grice) „начело сарадње” (уп. Грајс 1975) које подразумева да у разговору постоји идеја сарадње која обликује ироничне исказе да би говорник сугерисао и посредно наметнуо свој став, али да би сама сарадња и даље могла бити одржива.

Такође, издвајамо и теорију уљудности (engl. Politeness Theory, 1978), Брауна и Левинсона (Brown, Levinson), у којој се истиче критичка намера ироније, али уз чување сопственог достојанства, као и достојанства саговорника, у омогућавању наставка комуникације.

7 У овом правцу иду и касније прагматичке студије, засноване на анкетирању испитаника: „Ове студије сугеришу да говорници бирају иронију уместо директног, денотативног језика, у циљу духовитости, да би омекшали ивицу увреде, показали се да 
У анализама говорних чинова, проучавање ироније и сарказма везано је и за објашњење иронијске интенције и питања ефекта (Гибс, О Брајен и др. 1995), а у књижевно-уметничком делу је амбигвитет распрострањенији и чини основу поетског језика. ${ }^{8}$ Наиме, поред откривања интенције ироније у говорном чину, недовољно пажње је у теоријама ироније посвећено следећем аспекту: у књижевно-уметничком делу могуће је да књижевни лик нема интенцију стварања иронијског дискурса, али је реч о скривеној иронији у контексту тоталитета семантичког система књижевног дела.

Узмимо најочигледнији пример, да аутор кроз књижевне ликове износи мисли са којима се не слаже, већ их критикује и осуђује: у Брехтовој (Bertolt Brecht) драми Мајка храбрости и юена gеца, у идеји врбовника и наредника, да рат, наводно, успоставља ред и морал, заправо је реч о споју иронијског исказа и ироније ситуације, посредством критичке дистанце, односно објективне перспективе аутора, да рат управо означава супротно - немир, неморал, разарање и саморазарање, тако да је овде реч о скривеној ауторовој критици друштва. Врбовник: „Мир, то ти је тешки кркљанац. Тек рат васпостави ред” (Брехт 1964: 5). Након ове иронијске интенције Брехта, Врбовник прелази на сарказам: „Човечанство одвише пролиста за мирна времена" (Брехт 1964: 5). Посредством ироније, у свим слојевима: од исказа, до ироније ситуације у концепцији епског театра, Брехт тежи да разоткрије и осуди сваки систем ратног размишљања, приказујући Тридесетогодишњи рат (1618. до 1648. године), али заправо истовремено и сугеришући токове Другог светског рата, да би створио друштвено активног, слободоумног читаоца који ће разумети методе, али и иронију, сарказме и парадоксе нацизма и фашизма, и тако постати активни учесник у пацифистичкој мисији. Парафразе из Маринетијевог Манифестиа фууйризма и Хитлерове

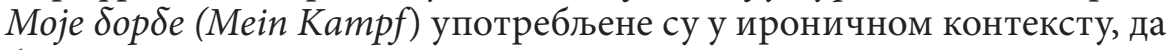
би Бертолд Брехт сугерисао своје антинацистичке идеје. Наведена скривена интенција дела може се интерпретирати у духу општег става Пола де Мана (Paul de Man): иронија и сама историја су „зачуђујуђе мећусобно повезане" (Ман 1996: 184).

Дакле, са становишта књижевног лика, у духу амбигвитета, мисао може бити изречена привидно дословно, а у ширем контексту критике друштва - реч је о ироничном исказу и у иронији ситуације,

контролишу њихове емоције и да не би нарушили свој однос са примаоцем” (Дјувс, Каплан и др. 1995: 347).

8 Милош Ковачевић истиче амбигвитет (амбигуитет) као кључни аспекат умножавања значења (Ковачевић 2012: 104) „јер амбигуитет представља неотуђиву унутрашњу одлику сваке поруке усредсређене на саму себе - укратко пратећу карактеристику поезије" (Јакобсон 1966: 313). Дакле, текст сугерише да читалац не треба да буде искључив и линеаран у интерпретацији, већ различита значења могу истовремено деловати у књижевном делу. Тако се, посредством амбигвитета, који се рачвају у нове комбинације, ствара многострукост значења дела. 
посредством које се остварује умножавање значења дела, у духу изграђивања објективне, критичке свести читаоца.

Поред ове димензије ироније коју прагматика није узела у обзир, због специјализованог поља проучавања усмереног на говорне чинове, постоји и још један аспекат који се односи на питања надмоћи, привидне друштвене или интелектуалне надмоћи, или пак - потчињености и пошиљаоца или примаоца ироничног исказа. Наиме, Грајсово (Grice) „начело сарадње”, као и „теорија уљудности” Брауна и Левинсона подразумевају дијалог, толеранцију, хуманост, жељу за сарадњом и очувањем достојанства, (онако како би у једном идеалном друштву требало да изгледа употреба ироније и комуникација уопште) тако да ове теорије имају највећу примену на анализу ироничних исказа говорника који имају равноправан положај у комуникацији, али постоји низ примера надмоћности друштвене улоге и става пошиљаоца, или, с друге стране - његовог потчињеног положаја, који може имати функцију скривене критике постојеће ситуације. У овом контексту, као допуну наведеним теоријама, предлажемо преиспитивање позиције надмоћности (Хобс 2011) пошиљаоца ${ }^{9}$ у употребама ироније и сарказма, која се може применити и на поље прагматике, као и на језик књижевно-уметничког дела (посебно у прозним делима епике и драме, које, поред основне, поетске функције језика, имају и елементе приказивања говорних чинова).

1. У очигледно надмоћном положају, пошиљалац примаоцу даје и објашњења значења ироније, јер једном остварени иронични исказ може постати скривени узрок будуће кулминације у коме ће бити имплициран. У овом процесу, иронија и сарказам постају обележја „непрестане жеље за моћи” (Хобс 2011: 94). На пример, у епском театру Мајке храбростии и юене gеце, наредник иронично, а често и саркастичним тоном, коментарише породицу Ане Фирлинг, зачуђен њиховим одсуством кохерентног породичног идентитета и гротескношћу (Проп 1984: 82) њихове појаве: „Морам признати, фина фамилија" (Брехт 1964: 9). Наредника не обавезују у овој ситуацији правила уљудности; он жели да иронија буде што очигледнија, да би показала надмоћ, али ипак не жели потпуно да их обезвреди, јер очекује материјалну корист од кантинерке, као и корист од њеног сина кога одводи у рат.

2. У случајевима у којима се креатор ироничног исказа налази у потчињеном положају, он тежи да сакрије ироничну намеру, али да је ипак посредно наговести - да би могао да се оправда ако

9 У ранијим проучавањима овог проблема постоји контрастирање, које ипак не узима у обзир и различите степене надмоћности и потчињености у дијалогу, као и различите природе употребе ироније у зависности од надмоћног или потчињеног положаја: „У психологији се сматра да настаје и у неколико разлога: или је израз сопствене осећајне немоћи која се компензира потребом за критиком, или потиче из осећања генијалне надмоћи које води духовитом поигравању с људима и односима (таква је романтичка иронија)" (Марицки Гађански, Лазаревић 1985: 275). 
надмоћни саговорник запита за смисао ироније и, према томе - ако постоји опасност да се надмоћни саговорник увреди. На пример, у Балканском шиичјуну Душана Ковачевића, карактеристична је ситуација у којој Илија и Ђура Чворовић, жртве друштвеног система, који касније постају џелати, киднапујући и ислеђујући подстанара Јаковљевића. „Иронија је известан начин изражавања. Она се, као што ћемо то видети, изражава не откривајући се, али се, на крају крајева, неминовно обраћа некој друштвеној средини" (Јанкелевич 1989: 42). Користећи иронију у питању порекла бесмислених и параноичних питања ислеђивања, Јаковљевић се као жртва заправо обраћа не само својим директним иследницима, већ и свим џелатима, као и друштвеним околностима које су их створиле: „Подстанар: Ко је састављао ова паметна и проницљива питања?” (Ковачевић 1987: $257)^{10}$ У случају потчињености пошиљаоца, иронични исказ резултат је сукоба осећања страха, у свести да би препозната иронија била аутодеструктивна, a, с друге стране - реакције која тежи скривеној побуни према постојећем стању потчињености.

\section{4. Питања аутономије сарказма}

У теорији књижевности, сарказам је посматран у контексту подређености иронији, од директнијег одређивања као њене врсте, или је пак, имплицитно констатован општи став да ако иронија тежи заједљивости онда прелази у сарказам. ${ }^{11}$ На пример, „иронија се јавља у више видова, од доброћудне шале, до заједљивог сарказма”. (Марицки Гађански, Лазаревић 1985: 275) Такође, Багић истиче полемички тон ироније и њен однос према сарказму: „Иронија је честа у полемици. Бритка је, обично се темељи на афективну наглашавању каква парадокса, неријетко се притом прелијева у сарказам (заједљиву, злобну иронију) или цинизам (дрску иронију)" (Багић 2012: 161). Такође, Хатиџа Крњевић истиче и заснованост сарказма на парадоксу: „Сарказам (јеткост) (...) термин античке реторике за врсту јетке ироније; сарказам је горка и немилосрдна поруга или прекор с подсмехом, заједљив и злонамеран. Сарказам је заснован на неком парадоксу, на нескладу између значења изречених речи и њиховог значења у контексту, што доводи до изразито пакосне поруге” (Крњевић 1985: 693).

Међутим, у наведеним примерима евидентно је да феномену сарказма треба посветити више пажње, пошто постоји констатација

10 Иронични искази у драмама Душана Ковачевића постали су изреке које се користе у свакодневној комуникацији као средства језичке игре, сатире и хумора.

113 разлику од прецизне одреднице ироније, драгоцене за разумевање феномена и, генерално, значаја Теорије књижевностии Зденка Лешића на просторима бивше Југославије, Лешић спомиње сарказам у општем смислу: „Грчки, sarcasmus, 'подругивање', врста је ироније у којој је поруга врло оштра и јетка” (Лешић 2010: 260). 
да иронија прелази у сарказам, али нису објашњени сложени разлози настанка и исходи сарказма, него су наведени крајњи исход и опште значење.

Наиме, за разлику од основног значења ироније, пошто „иронија функционише тако што у исто вријеме и крије право значење и на неки начин сугерише какво је оно” (Лешић 2010: 248), сарказам ипак може имати интенцију да буде откривенији, а може бити и директнији од основних облика ироније. У овом контексту, треба имати у виду степене увредљивости и откривања сарказма, као и степене блискости или специфичности сарказма са основним одликама ироније - претварањем и противречношћу, пошто је евидентно да „постоје индивидуалне разлике у наводној употреби сарказма које утичу на тумачење и обраду вербалне ироније” (Иванко, Пексман и др. 2004: 244).

Да бисмо објаснили сложене односе ироније и сарказма неопходно је да обухватимо резултате истраживања говорних чинова, као и примере сарказма у књижевно-уметничком делу.

Управо да би сугерисала питања прелаза од ироније ка сарказму у говору, Јулија Јоргенсен (Julia Jorgensen), поред термина „сарказам”, користи и термин „саркастична иронија” “"Sarcastic Irony”) редак термин у нашем говорном подручју), закључујући да се и при употреби сарказма, ипак „резултати показују да сарказам може послужити функцији чувања достојанства (чувања образа: face-saving) , тако да се говорник чини мање грубим и неправичним, посебно када изражава уобичајену критику (Јоргенсен 1996: 613). Дакле, у овом облику, сарказам се може тумачити као врста ироније.

С друге стране, фокусирајући се на реакцију примаоца, Меги Топлак (Maggie Toplak) и Алберт Кац (Albert N. Katz) истичу да постоје и разлике у тачки гледишта, које указују на то да се ефекат (сарказма) који говорник верује да је остварио, понекад разликује од реалног ефекта који је остављен на особу којој је сарказам упућен, односно - да прималац, посредством претварања, имајући интенцију „чувања образа”, ипак код примаоца оставља утисак оштрије заједљивости (Топлак, Кац 2000: 1467).

У наведеним аспектима разматрали смо директније или индиректније покушаје саркастичног „претварања”, запажајући да су такви принципи иманентни и иронији (те се самим тим и сарказам у тим случајевима може сматрати и врстом ироније). Међутим, у случајевима у којима је сарказам директније природе - не можемо говорити о хуманистичком обзиру пошиљаоца према примаоцу. На пример, у Теорији кюижевностии, Драгиша Живковић не наводи директно да је сарказам врста ироније (али, ипак, дефинисање сарказма није графички одвојено као посебно поглавље):

Када је иронија нарочито заједљива и увредљива, она прелази у сарказам (грчки sarx = месо; у месо засећи), у Смрӣи Смаил Аїe Ченіића 
описује се како гладна раја вапи за хлебом. А Смаил-ага јој саркастично одговара: „(...) Печења ћу мјеште хљеба!” - мислећи на то како ће је мучити (једна врста мучења била је и та да се хришћанин обеси за ноге, а одозго се наложи ватра на којој се он дими и пече) (Живковић 1971: 88-89).

Наиме, Драгиша Живковић је у овом случају имплицирао и случајеве аутономије сарказма, а ми ћемо на овом месту прецизирати наведену импликацију: сврха је ироније да ипак сакрије значење и да постоји одређено противуречје (Ковачевић 2000), а ако су основа ироније: претварање, супротност и противречност, у овом примеру не постоји ниједна од наведених димензија, већ је присутна директна увреда хришћанског идентитета. Смаил-ага позива на масовна мучења и убиства, тако да се смисао директно открива као претња, а у овом примеру нема противуречја. Такође, особина сарказма схваћеног као „заједљиве, злобне ироније” (Багић 2012: 161) остаје ипак претварање, а ако не постоји макар и привидно претварање можемо говорити о специфичним случајевима аутономије сарказма у односу на иронију.

Дакле, све што сарказам више тежи, макар и привидно (метафорично речено) да сачува образ оба саговорника (face-saving) и да тако омогући настанак комуникације, тиме је он ближи иронији, а што је откривенији, директнији и ако не задржава смисао претварања и супротности, противречности, онда он самим тим има самосталнија поља деловања.

\section{5. Иронија и сарказам у контексту сатире и пародије}

Пошто иронија и сарказам представљају фигуре критике, самим тим је иронија „у темељу или је битан састојак сатире и пародије, пастиша, сарказма, цинизма и хумора" (Багић 2012: 165).

Сходно теми нашег рада, везаној за опште аспекте, у овом поглављу наводимо дела из српске књижевности у чијим насловима је већ евидентан иронијски дискурс. На пример, Роgољуйци Јована Стерије Поповића представљају осуду лажног родољубља; у претварању да говори у име великих идеја, лажно родољубље бива употребљено за стицање личне користи. Иронија се може у ужем смислу пренети на историјске околности у Војводини у 19. веку, али и на све прошле и будуће злоупотребе великих националних идеја, не само у српској историји, него и у ширем контексту светске књижевности.

Такође, иронија и сатира могу се у књижевном делу преплитати и са пародијом. На пример, Јуйиуйунска нароgна химна Јована Јовановића Змаја већ својим насловом упућује на пародију химне - узимајући тон химне, али негирајући њену сврху, јер није реч о химни посвећеној народу, него о слепој посвећености владару; даље, поред тога што ова песма представља критику народног менталитета, тре- 
ба је посматрати у тоталитету са песмом Јуйуйунска јухахаха, као критику режима, јер и реч „Јутутунци” већ има саркастичан призвук, како према владару тако и према народном менталитету, зато што упућује на заслепљеност, немогућност сопственог мишљења и неговање „основне врлине” послушности, у њиховом незнању, као и „срећи” изазваној празним обећањима власти.

Након ових романтичарских сатиричних стихова, прелазимо на примере из реалистичке приповетке, да бисмо прецизирали односе ироније и сарказма:

Сатира као књижевни облик исмевања друштвених изопачености може бити тако жестока да прелази у сарказам (...) али када у Даніи приповедач сања поданике неке државе који се отимају да им што пре буде врелим гвожђем ударен жиг на чело, његова сатира постаје сарказам (Тартаља 1998: 63).

Допунићемо ову Тартаљину драгоцену опсервацију за разумевање сарказма и ставом да је у сатиричној приповеци Данї циљ Радоја Домановића био да (директнијом саркастичном сликом него у Сїраguju) утиче на буђење самокритичности код читаоца, да понизи (Хатиџа Крњевић 1985: 693) следбенике ропског менталитета, али да представи отворенију осуду друштва која се не може постићи блажим облицима ироније. Као закључни део овог поглавља треба споменути и Boђу, чија се универзална иронија обраћа свим прошлим и будућим „вођама” и тако се непрестано обнавља дијалог читаоца са Радојем Домановићем, као претходником и савремеником.

На основу наведених аспеката, закључујемо да иронични и саркастични искази, у општем контексту ироније ситуације, представљају реакције на постојеће друштвено стање, а могу прећи и у побуну према друштвеном систему. Према томе, иронија може имати ширу примену, од духовите изреке, хумореске, скривене сатире (Проп 1984: 111), трагикомичног виђења света, до преласка у саркастично огорчење према друштвеним околностима.

\section{6. Закључак}

У проучавању општих одлика ироније успоставили смо компаративну анализу поимања ироније: од реторичких, преко прагматичких, до стилистичких и филозофских домена. На тај начин смо објединили синхронијску и дијахронијску перспективу и одредили претварање, супротност значења и противуречност као иманентне одлике иронијског дискурса.

Након ове теоријске основе, логичан наставак рада био је везан за облике ироније, при чему смо истакли специфичности, раслојавања и дифузност феномена ироније. Такође, у анализи иронијских интенција било је неопходно остварити комплементарност, али и 
одредити специфичности стилистичких и прагматичких проучавања. Да бисмо расветлили узроке степена прикривања ироније, имали смо у виду значај „теорије уљудности” и „теорије сарадње” у комуникацији; истакли смо да се такве особине превасходно могу препознати у дијалозима равноправних говорника. Ове теорије допунили смо односима надмоћи и потчињености у комуникацији, као честим факторима које постоје у говорним чиновима и у књижевно-уметничком делу. На основу ових анализа, истакли смо да је иронични исказ ипак откривенији и има знатно мање обзира према правилима уљудности, ако пошиљалац поседује надмоћни положај у комуникацији.

На тај начин смо отворили питања аутономије сарказма. Запазили смо да се они примери сарказма који ипак у својој основи имају основна обележја иронијског дискурса (претварање, противречност, супротност значења) могу сматрати врстама јетке ироније, док примери сарказма који немају изражене наведене особине већ поседују отворенији, директнији став - самим тим имају свој самосталнији домен деловања. Такође, примери ироније који прелазе у сарказам најчешћи су у оним случајевима у којима пошиљалац поседује осећај надмоћности над примаоцем.

У последњем поглављу рада истакли смо значај употребе ироније и сарказма у грађењу сатире и пародије. У овом контексту, иронија и сарказам представљају духовита запажања којима се могу описати кључни елементи друштвених промена, да би се истовремено приказао и разоткрио друштвени систем, у циљу отварања конструктивне полемике и пружања критичког одговора, као неопходног услова за изграђивање свести слободоумног интелектуалца.

\section{ИЗВОРИ}

Breht, Bertold. Majka hrabrost i njena deca. Preveli sa nemačkog Tatjana Šenk i Jovan Ćirilov. Beograd: Rad, 1964.

Домановић, Радоје. Сабрана gела. Крагујевац: Кораци, 2009.

Јовановић-Змај, Јован. Полийичке и сайиричне йесме. Нови Сад: Матица српска, 1979.

Ковачевић, Душан. Изабране gраме. Београд: Нолит, 1987.

Popović, Sterija, Jovan. Rodoljupci: veselo pozorište u pet dejstvija. Beograd: Ringier Axel Springer, 2013. 


\section{ЛИТЕРАТУРА}

Aristotel. Nikomahova etika. Prevela sa starogrčkog Radmila Šalabalić. Beograd: BIGZ, 1980.

Aristotel. Retorika 1, 2, 3. Preveo sa starogrčkog Marko Višić. Novi Sad: Svetovi, 1997.

Aristotel. O pesničkoj umetnosti. Preveo sa starogrčkog Miloš N. Đurić. Beograd: Dereta, 2002.

Bagić, Krešimir. Rječnik stilskih figura. Zagreb: Školska knjiga, 2002.

Werkmann, Ana. „Ironični iskazi i Griceovo načelo suradnje”. Hrvatistika 5 (2011): 135-144.

Wilson Deirdre and Dan Sperber. "Irony and the Use-Mention distinction". Radical Pragmatics. Ed. Peter Cole. New York: Academic Press, 1981. 295-318.

Wilson Deirdre and Dan Sperber. "On verbal irony”. Lingua 87 (1992): 53-76.

Gibbs, Raymond, Jennifer E. O’Brien and Shelly Doolittle. "Inferring meanings that are not intended: Speakers' intentions and irony comprehension". Journal Discourse Processes 20.2 (1995): 187-203.

Grice, Paul. "Logic and Conversation”. Syntax and Semantics. Vol. 3: Speech Acts. Ed. by Peter Cole and Jerry L. Morgan. New York: Academic Press, 1975. 41-58.

Dews, Shelly, Joan Kaplan and Ellen Winner. "Why not say it directly? The social functions of irony”. Discourse Processes, 19. 3 (1995): 347-367.

Živković, Dragiša. Teorija književnosti sa teorijom pismenosti. Beograd: Naučna knjiga; Sarajevo: Svjetlost, 1971.

Живковић, Душан. „Иронија у контексту друштвених промена и конструкције идентитета у драми Балкански шйијун Душана Ковачевића". Савремено ярушичво и криза ирроучавана језика и књижевностии. Ур. Милош Ковачевић и Драган Бошковић. Крагујевац: Филолошко-уметнички факултет, 2012. 341-355.

Ivanko, Stacey, Penny Pexman and Kara Olineck. "How Sarcastic are You? Individual Differences and Verbal Irony”. https://www.researchgate. net/publication/247744086_How_Sarcastic_are_YouIndividual_ Differences_and_Verbal_Irony, University of California. 6. 11. 2017.

Jakobson, Roman. Lingvistika i poetika. Prevela s ruskog Draginja Pervaz. Beograd: Nolit, 1966.

Jankelevič, Vladimir. Ironija. Preveo s francuskog Branko Jelić. Sremski Karlovci: Izdavačka knjižarnica Zorana Stojanovića, 1989.

Jorgensen, Julia. „The functions of sarcastic irony in speech”. Journal of Pragmatics, 26 (1996): 613-634.

Kvintilijan, Marko Fabije. Obrazovanje govornika. Preveo sa latinskog Petar Pejčinović. Sarajevo: Veselin Masleša, 1985.

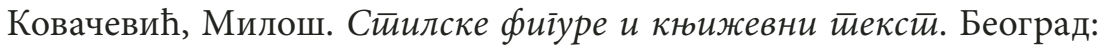
Требник, 1998. 


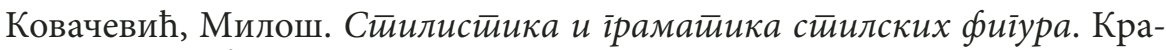
гујевац: Кантакузин, 2000.

Ковачевић, Милош. Сйuси о сйилу и језику. Бања Лука: Књижевна задруга, 2006.

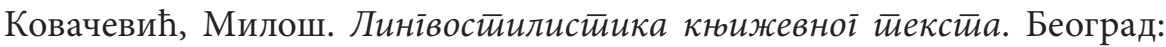
CK3, 2012.

Крњевић, Хатиџа. „Сарказам”. Речник книжевних иеермина. Ур. Драгиша Живковић, Београд: Нолит, 1985. 693.

Лешић, Зденко. Теорија кюижевностии. Београд: Службени гласник, 2010.

Man, Paul De. „The concept of irony”. Aesthetic Ideology. Minneapolis: University of Minnesota, 1996.

Марицки Гађански, Ксенија и Предраг Лазаревић. „Иронија”. Речник кьижевних йермина. Ур. Драгиша Живковић. Београд: Нолит, 1985. 275-276.

Platon. Meneksen; Fileb; Kritija. Prevela sa grčkog Ksenija Maricki Gađanski. Beograd: BIGZ, 1983.

Popović, Tanja. Rečnik književnih termina. Beograd: Logos Art, 2007.

Prop, Vladimir. Problemi komike i smeha. Preveo s ruskog Bogdan Kosanović. Novi Sad: Dnevnik: Književna zajednica, 1984.

Solar, Milivoj. Teorija književnosti. Beograd: Službeni glasnik, 2012.

Стојановић, Драган. Иронија и значене. Београд: Завод за уџбенике и наставна средства, 2003.

Schoentjes, Pierre. Poetique de l'ironie. Paris: Seuil, 2001.

Тартаља, Иво. Теорија книжевносити. Београд: Завод за уџбенике и наставна средства, 1998.

Toplak, Maggie and Albert Katz. "On the uses of sarcastic irony". Journal of Pragmatics, 32.10(2000): 1467-1488.

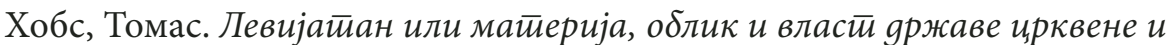
iрађанске. Превео с енглеског Миливоје Марковић. Београд: Правни факултет Универзитета у Београду, 2011.

Dušan R. Živković

General Relations Between Irony and Sarcasm

Summary

The paper presents an analysis of the nature, forms and functions of irony and sarcasm, from the process of creating and perceiving ironic and sarcastic statements, to their effects and interferences within the framework of the irony discourse, to the structuring and outcome of the irony of a situation in the speech act 
and in the literary and art works, considering the following aspects: 1 . the general features of irony, 2. the classifications of forms of irony, 3. the intentions of irony, 4. the questions of autonomy of sarcasm, 5 . the relations between irony and sarcasm in the context of satire and parody. We have studied the general relations of irony and sarcasm through an interdisciplinary approach: from the rhetorical, to pragmatic, to stylistic and philosophical domains. In this way, we combined the synchronic and diachronic perspectives, using the analytical-synthetic method.

"Conversion" is the basic feature of irony, the purpose of which is primarily the meaning opposite to the one apparently expressed. Contradiction is also at the core of irony, while the examples of relaxed expressions are much less frequent and therefore represent only exceptions to the rules, both in a speech act and in literary works. Still, the examples of politeness in ironic statements need to be precise, without disputing the theory of the "opposite meaning», but in order to gain awareness of the variations, layers, and nuances of irony.

Our scholarly contribution also consists in considering the relationship of superiority and subordination in ironic and sarcastic statements and situations, the degrees of suggestion, concealment and the discovery of the irony intent, as well as the issues where sarcasm represents a kind of irony, in relation to the cases which show a more autonomous position of sarcasm in relation to the immanent features of irony.

We noticed that there are instances of sarcasm which, however, in their basis have the fundamental characteristics of the ironic discourse (conversion, contradiction, contrast of meanings) and can be considered as types of irony, while the examples of sarcasm that do not have the expressions mentioned above already have a more open, more direct attitude - its more independent domain of action. Also, examples of irony turning into sarcasm are the most common in those cases where the sender has a sense of superiority over the recipient.

On the other hand, in a broader sense of the relation between irony and sarcasm, towards parody and irony, we conclude that ironic and sarcastic statements, in the general context of social criticism and situational irony, represent reactions to the existing social state, and they can also turn into a hidden revolt. Therefore, irony can have a wider application, from a witty saying, a humorous, hidden satire, a tragicomic vision of the world, to the transition to sarcastic indignation over social circumstances.

Keywords: irony, sarcasm, interdisciplinarity, ironic intention, opposites, satire, parody. 